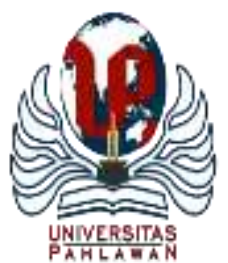

Edukatif : Jurnal Ilmu Pendidikan Volume 3 Nomor 5 Tahun 2021 Halm 3173 - 3180 EDUKATIF: JURNAL ILMU PENDIDIKAN

Research \& Learning in Education

https://edukatif.org/index.php/edukatif/index

\title{
Peningkatan Keaktifan Belajar Siswa dengan Menerapkan Model Pembelajaran Kooperatif Tipe Student Team Achievement Divisions (STAD)
}

\author{
Nur Rokhanah $^{1 凶}$, Asri Widowati ${ }^{2}$, Eko Hari Sutanto ${ }^{3}$ \\ Universitas Negeri Yogyakarta, Indonesia ${ }^{1,2}$, Sekolah Dasar Negeri Godean 1 Sleman, Indonesia ${ }^{3}$ \\ E-mail : nur.rokhanah@gmail.com ${ }^{1}$, asri widowati@uny.ac.id ${ }^{2}, \underline{\text { ekoharisutanto@ @mail.com }}^{3}$
}

\begin{abstract}
Abstrak
Penelitian ini dilatarbelakangi oleh rendahnya keaktifan belajar siswa di kelas V SD Negeri 3 Sidoluhur. Tujuan penelitian ini untuk meningkatkan keaktifan belajar siswa dengan menerapkan model pembelajaran kooperatif tipe Student Team Achievement Divisions (STAD). Jenis penelitian ini adalah Penelitian Tindakan Kelas (PTK) yang dilaksanakan dalam dua siklus. Teknik pengumpulan data penelitian ini mengggunakan observasi, kuesioner, dan dokumentasi. Subjek penelitian yaitu seluruh siswa kelas V SD Negeri 3 Sidoluhur yang berjumlah 29 siswa. Hasil penelitian menunjukkan adanya peningkatan keaktifan belajar siswa dengan menerapkan model pembelajaran kooperatif tipe STAD. Pada siklus I terdapat 21 siswa dengan kategori keaktifan belajar tinggi, 6 siswa dengan kategori sedang, dan 2 siswa dengan kategori rendah. Persentase keaktifan belajar siswa pada siklus I mencapai 69.5\%. Pada siklus II terdapat 27 siswa dengan kategori keaktifan belajar tinggi dan 2 siswa dengan kategori sedang. Persentase keaktifan belajar siswa pada siklus II mencapai 82.4\%. Simpulan dari penelitian ini adalah bahwa model pembelajaran kooperatif tipe STAD dapat meningkatkan keaktifan belajar siswa.
\end{abstract}

Kata Kunci: Pembelajaran Kooperatif, Student Team Achievement Divisions, Keaktifan Belajar

\begin{abstract}
This research is motivated by the low student learning activity in the fifth grade of SD Negeri 3 Sidoluhur. The purpose of this research is to improve student learning activity by applying of cooperative learning model type STAD. This type of research is classroom action research $(C A R)$ which is carried out in two cycles. This research data collection technique using observation, questionnaires, and documentation. The research subjects were 29 students of fifth grade of SD Negeri 3 Sidoluhur. The results showed that there was an increase in students' active learning by applying the cooperative learning model type STAD. In the first cycle, there were 21 students in the high learning activity category, 6 students in the medium category, and 2 students in the low category. The percentage of student learning activity in the first cycle reached $69.5 \%$. In the second cycle, there were 26 students in the high learning activity category and 2 students in the medium category. The percentage of student learning activity in the second cycle reached $82.4 \%$. The conclusion of this study is that the cooperative learning model type STAD can improve student learning activities.
\end{abstract}

Keywords: Cooperative Learning, Student Team Achievement Divisions, Learning Activity

Copyright (c) 2021 Nur Rokhanah, Asri Widowati, Eko Hari Sutanto

$\triangle$ Corresponding author

Email : nur.rokhanah@gmail.com

DOI : https://doi.org/10.31004/edukatif.v3i5.860

ISSN 2656-8063 (Media Cetak)

ISSN 2656-8071 (Media Online)

Edukatif : Jurnal Ilmu Pendidikan Vol 3 No 5 Tahun 2021 p-ISSN 2656-8063 e-ISSN 2656-8071 
3174 Peningkatan Keaktifan Belajar Siswa dengan Menerapkan Model Pembelajaran Kooperatif Tipe Student Team Achievement Divisions (STAD) - Nur Rokhanah, Asri Widowati, Eko Hari Sutanto DOI: https://doi.org/10.31004/edukatif.v3i5.860

\section{PENDAHULUAN}

Pendidikan merupakan salah satu faktor penting dalam upaya menyongsong era revolusi 4.0. Hal ini karena sumber daya manusia yang berkualitas dapat diciptakan dengan adanya pendidikan yang berkualitas pula. Selain itu, pendidikan yang berkualitas juga dapat menjadi salah satu sarana untuk mencapai keberhasilan pembangunan nasional.

Pendidikan di Indonesia seperti yang tercantum dalam Undang-Undang Nomor 20 Tahun 2003 tentang Sistem Pendidikan Nasional bertujuan untuk mengembangkan potensi peserta didik agar menjadi manusia yang beriman dan bertakwa kepada Tuhan Yang Maha Esa, berakhlak mulia, sehat, berilmu, cakap kreatif, mandiri, dan menjadi warga negara yang demokratis serta bertanggung jawab. Untuk mewujudkan tujuan pendidikan nasional maka proses belajar mengajar perlu dilakukan pembenahan.

Proses belajar mengajar yang dahulu berpusat pada guru dengan menjadikan guru sebagai satu-satunya sumber belajar kini harus mengalami perubahan. Proses belajar mengajar saat ini harus berpusat pada siswa. Peran guru saat ini adalah sebagai fasilitator dalam proses pembelajaran. Dalam rangka meningkatkan kualitas pembelajaran, guru harus menciptakan kondisi belajar yang aktif dan kreatif. Kegiatan pembelajaran harus menantang, mendorong eksplorasi, memberikan pengalaman sukses, dan mengembangkan kecakapan berfikir siswa (Dimyati \& Mudjiono, 2006).

Pembelajaran yang berpusat pada siswa menuntut siswa untuk aktif dalam pembelajaran. Keaktifan dalam belajar merupakan unsur penting bagi keberhasilan pembelajaran. Belajar yang berhasil harus melalui berbagai macam aktivitas, baik aktivitas fisik maupun psikis (Sinar, 2018). Adapun keaktifan belajar dapat diartikan sebagai perubahan tingkah laku atau emosi yang mengarah kepada upaya belajar (Wahyuningsih, 2020). Senada dengan pendapat tersebut, keaktifan belajar juga dapat diartikan sebagai suatu proses pembelajaran yang timbul akibat respon siswa aktif ketika pembelajaran berlangsung (Putri \& Widodo, 2017). Dengan demikian dapat disimpulkan bahwa keaktifan belajar merupakan segala kegiatan yang dilakukan selama proses pembelajaran sebagai indikator adanya keingintahuan siswa untuk belajar.

Keaktifan belajar terbagi menjadi beberapa jenis. Paul B. Diedric dalam (Sardiman, 2011) membuat suatu daftar aktivitas siswa yang dapat digolongkan sebagai berikut: 1) visual activities seperti membaca, memperhatikan gambar, demonstrasi, percobaan, pekerjaan orang lain dan sebagainya; 2) oral activities seperti menyatakan, merumuskan, bertanya, memberi saran, mengeluarkan pendapat, mengadakan interview, diskusi, interupsi dan sebagainya; 3) listening activities seperti mendengarkan uraian, percakapan, diskusi, musik,pidato, dan sebagainya; 4) writing activities seperti menulis cerita, karangan, laporan, tes, angket, menyalin, dan sebagainya; 5) drawing activities seperti menggambar, membuat grafik, peta diagram, pola, dan sebagainya; 6) motor activities seperti melakukan percobaan, membuat konstruksi, model, mereparasi, bermain, berkebun, memelihara binatang dan sebagainya; 7) mental activities seperti menanggapi, mengingat, memecahkan soal, menganalisis, melihat hubungan, mengambil keputusan, dan sebagainya; dan 8) emotional activities seperti menaruh minat, merasa bosan, gembira, berani, tenang, gugup, dan sebagainya.

Keaktifan belajar siswa dapat diamati selama proses pembelajaran. Maka indikator keaktifan belajar ini, terlibat dalam keikutsertaan memecahkan masalah, bertanya kepada siswa lain atau guru apabila tidak memahami persoalan yang dihadapi, berusaha mencari berbagai informasi yang diperlukan untuk memecahkan masalah, serta menilai kemampuan diri sendiri dan hasil-hasil yang diperoleh (Sudjana, 2006). Keaktifan belajar siswa dapat diamati dalam setiap tahap kegiatan pembelajaran, baik kegiatan belajar kelompok maupun belajar secara perseorangan.

Keaktifan belajar siswa dalam kegiatan pembelajaran dipengaruhi oleh berbagai faktor. Faktor-faktor yang mempengaruhi keaktifan peserta didik dibedakan menjadi dua, yaitu faktor intern dan faktor ekstern. Faktor intern yaitu memiliki badan sehat, memiliki intelegensi, siap untuk melakukan kegiatan belajar, memiliki bakat dalam diri, memiliki pengalaman yang berkaitan dengan belajar. Sedangkan faktor ekstern 
yaitu adanya motivasi belajar, bahan pelajaran yang digunakan menarik dan mudah dimengerti peserta didik, adanya alat bantu belajar (media pembelajaran), dan suasana belajar yang nyaman (Hamalik, 2009). Selain faktor tersebut, faktor yang mempengaruhi keaktifan belajar yaitu faktor fisiologis dan faktor psikologis. Secara fisiologis, keadaan fisik yang sehat dapat menunjang kegiatan yang dilakukannya. Adapun aspek-aspek yang mempengaruhi kondisi belajar dan keaktifan peserta didik antara lain: aspek genetik dan aspek kekurangan panca indera. Sedangkan faktor-faktor psikologis yang dikatakan memiliki peran penting itu dapat dipandang sebagai cara untuk melihat berfungsi atau tidaknya pikiran peserta didik dalam proses pembelajaran untuk pemahaman dan penguasaan bahan pelajaran. Faktor faktor tersebut yaitu: motivasi, konsentrasi, pemahaman dan mengulang pelajaran (Slameto, 2003). Dari beberapa pendapat yang telah diuraikan dapat disimpulkan bahwa secara garis besar faktor yang mempengaruhi keaktifan belajar siswa yaitu faktor intern (dari dalam diri siswa) dan faktor ekstern (dari luar diri siswa).

Pada kenyataannya, dalam mewujudkan pembelajaran yang berpusat pada siswa masih terdapat kendala. Hasil observasi awal di kelas V SD Negeri 3 Sidoluhur yang dilaksanakan pada hari Senin, 11 Januari 2021 ditemukan bahwa pembelajaran di kelas $\mathrm{V}$ masih belum maksimal. Pada proses pembelajaran siswa kurang memperhatikan penjelasan guru, jarang bertanya kepada guru maupun teman tentang materi yang belum jelas, kurang percaya diri dalam menyampaikan pendapat, sering bermain sendiri ketika pembelajaran, dan kurang antusias dalam proses pembelajaran. Pada kegiatan observasi terdapat 2 siswa termasuk kategori keaktifan belajar tinggi, 5 siswa termasuk kategori keaktifan belajar sedang, dan sisanya 22 siswa termasuk kategori keaktifan belajar rendah. Persentase keaktifan belajar siswa hanya 52.5\% (rendah). Dengan demikian, dapat disimpulkan bahwa keaktifan belajar siswa kelas V SD Negeri 3 Sidoluhur masih rendah.

Berdasarkan fakta yang telah dipaparkan, penyebab rendahnya keaktifan belajar siswa diduga karena guru belum menerapkan model pembelajaran yang melibatkan partisipasi aktif siswa. Model pembelajaran yang digunakan oleh guru masih bersifat konvensional dan berpusat pada guru. Untuk mengatasi masalah tersebut, peneliti berkolaborasi dengan guru kelas $\mathrm{V}$ memilih alternatif tindakan yaitu dengan menerapkan model pembelajaran kooperatif tipe Student Team Achievement Divisions (STAD).

Model pembelajaran adalah suatu perencanaan atau suatu pola yang digunakan sebagai pedoman dalam merencanakan pembelajaran di kelas (Handayani, 2019). Model pembelajaran dibagi menjadi beberapa jenis, salah satunya model pembelajaran kooperatif. Pembelajaran kooperatif adalah cara siswa bekerjasama dalam tim dengan anggota yang heterogen (Slavin, 2011). Secara lebih rinci, pembelajaran kooperatif adalah metode yang lebih spesifik dari collaborative learning, yaitu siswa bekerja bersama-sama, berhadapan muka dalam kelompok kecil dan melakukan tugas yang sudah terstruktur (Lubis, 2012). Pembelajaran kooperatif bertujuan meningkatkan kemampuan akademik siswa, menumbuhkan rasa toleransi, dan meningkatkan keterampilan sosial.

Model pembelajaran kooperatif terbagi menjadi beberapa tipe, salah satunya tipe Student Team Achievement Divisions (STAD). Model pembelajaran kooperatif tipe Student Team Achievement Divisions (STAD) merupakan salah satu tipe dari model pembelajaran kooperatif dengan menggunakan kelompokkelompok kecil dengan jumlah anggota tiap kelompok 4-5 orang siswa secara heterogen (Trianto, 2013). Secara lebih rinci, dalam model pembelajaran kooperatif tipe STAD siswa ditempatkan dalam tim belajar beranggota 4-5 orang yang merupakan campuran menurut tingkat prestasi, jenis kelamin, dan suku. Guru menyajikan pelajaran, dan kemudian siswa bekerja dalam tim mereka memastikan bahwa seluruh anggota tim telah mengusai pelajaran tersebut. Kemudian, seluruh siswa diberikan tes tentang materi tersebut, pada saat tes ini mereka tidak diperbolehkan saling membantu (Slavin, 2011). Dengan demikian dapat disimpulkan bahwa model pembelajaran kooperatif tipe Student Team Achievement Divisions (STAD) merupakan model pembelajaran yang menggunakan kelompok kecil siswa dengan level kemampuan akademik yang berbedabeda untuk mencapai tujuan pembelajaran. 
Model pembelajaran kooperatif tipe STAD terdiri dari beberapa fase atau langkah. Adapun langkahlangkah model pembelajaran kooperatif tipe STAD yaitu: (1) penyampaian tujuan dan motivasi; (2) penyampaian informasi; (3) mengorganisasikan siswa ke dalam kelompok kooperatif; (4) membimbing kelompok bekerja dan belajar; (5) evaluasi; dan (6) pemberian penghargaan (Wijaya \& Arismunandar, 2018). Pada model pembelajaran kooperatif tipe STAD aktivitas belajar lebih banyak berpusat pada siswa. Dalam penerapannya model kooperatif tipe STAD tidak hanya menginginkan kinerja akademik, tetapi juga melatih siswa dalam mencapai tujuantujuan hubungan sosial yang pada akhirnya berpengaruh pada prestasi akademik siswa (Saragih, 2013).

Model pembelajaran kooperatif tipe STAD juga memiliki berbagai kelebihan. Dengan model pembelajaran kooperatif tipe STAD, guru merasa lebih ringan pekerjaannya, karena untuk memahami materi pelajaran guru sudah dibantu oleh siswa sehingga penanganan kesulitan belajar siswa lebih mudah. Bagi siswa dapat memperoleh pengalaman hidup bersama melalui kerja sama dalam kelompok, mampu memberikan sikap positif dan percaya diri, karena dalam pembelajaran ada saling ketergantungan positif. Ketergantungan semacam ini selanjutnya akan memunculkan tanggung jawab individu terhadap kelompok dan keterampilan interpersonal dari setiap anggota kelompok (Sunilawati et al., 2013). Selain itu model pembelajaran kooperatif tipe STAD membantu menumbuhkan kompetensi siswa, berpikir kritis dan mengembangkan sikap sosial sehingga dapat meningkatkan motivasi, dan aktivitas belajar siswa (Harahap, 2013). Adapun keunggulan model pembelajaran kooperatif tipe STAD dibanding model pembelajaran lain yaitu: (1) meningkatkan hubungan antarindividu, karena setiap siswa berpeluang sama untuk terlihat aktif, interaksi yang lebih banyak saling membagi tanggung jawab dan saling mengisi; (2) memberikan dukungan kepada interaksi siswa, karena akan tertanam sikap saling menghargai pendapat teman yang berbakat cerminan dari sikap ilmiah, meningkatkan ketekunan, ketabahan, dan keuletan dalam mengerjakan tugas-tugas; (3) memupuk rasa percaya diri dan meningkatkan aktualitas konsep diri masing-masing siswa; (4) siswa menjadi senang (puas) dengan pengalaman belajar mereka; dan (5) membantu siswa mengembangkan kemampuan berkomunikasi (Suparsawan, 2020). Dengan demikian dapat disimpulkan bahwa kelebihan model pembelajaran kooperatif tipe STAD yaitu meningkatkan hubungan antar individu, memberikan dukungan kepada interaksi siswa, memupuk sikap positif dan percaya diri siswa, mengembangkan kemampuan berkomunikasi, dan meningkatkan motivasi dan aktivitas belajar siswa.

Berdasarkan permasalahan yang telah diuraikan, maka tujuan penelitian ini yaitu untuk meningkatkan keaktifan belajar siswa di kelas V SD Negeri 3 Sidoluhur tahun ajaran 2020/2021 dengan menerapkan model pembelajaran kooperatif tipe Student Team Achievement Divisions (STAD).

\section{METODE PENELITIAN}

Jenis penelitian ini adalah Penelitian Tindakan Kelas (PTK). Penelitian tindakan kelas dapat diartikan sebagai proses pengkajian masalah pembelajaran di dalam kelas dalam upaya untuk memecahkan masalah dengan cara melakukan berbagai tindakan yang terencana serta menganalisis setiap pengaruh dari perlakuan tersebut (Sanjaya, 2013). Desain penelitian ini yaitu model Kemmis dan Mc Taggart, meliputi empat tahapan diantaranya perencanaan, pelaksanaan tindakan, observasi dan refleksi.

Penelitian tindakan kelas ini dilaksanakan di SD Negeri 3 Sidoluhur tahun ajaran 2020/2021. Subjek penelitian ini adalah siswa kelas $\mathrm{V}$ yang berjumlah 29 siswa yang terdiri dari 17 siswa laki-laki dan 12 siswa perempuan. Jenis data penelitian ini adalah data kuantitatif dan data kualitatif. Sumber data dalam penelitian ini yaitu siswa kelas V. Teknik pengumpulan data yang digunakan dalam penelitian ini yaitu melalui observasi, kuesioner, dan dokumentasi. Uji validitas data menggunakan triangulasi teknik dan sumber. Analisis data meliputi reduksi data, penyajian data, dan kesimpulan sesuai dengan model analisis data menurut Miles dan Huberman (Sugiyono, 2012). 
Penelitian ini dilaksanakan dalam dua siklus dengan dua pertemuan untuk masing-masing siklusnya. Siklus I dilaksanakan pada 22-23 Maret 2021 dengan materi tema 8 Lingkungan Sahabat Kita, subtema 1 Manusia dan Lingkungan, pembelajaran 3 dan 4. Siklus II dilaksanakan pada 5-6 April 2021 dengan materi tema 8 Lingkungan Sahabat Kita, subtema 2 Perubahan Lingkungan, pembelajaran 3 dan 4.

Indikator keberhasilan penelitian ini adalah apabila terdapat $75 \%$ siswa dalam kelas yang terlibat aktif dalam pembelajaran di kelas. Pembelajaran dikatakan berhasil dan berkualitas dari segi proses apabila seluruhnya atau setidak-tidaknya sebagian besar $(75 \%)$ siswa terlibat secara aktif, baik fisik, mental, maupun sosial dalam pembelajaran.

\section{HASIL DAN PEMBAHASAN PENELITIAN}

Penelitian tindakan kelas ini dilakukan untuk meningkatkan keaktifan belajar siswa kelas V SD Negeri 3 Sidoluhur. Sebelum melaksanakan tindakan, peneliti melakukan observasi pembelajaran untuk mengetahui kondisi awal keaktifan belajar siswa. Hasil observasi prasiklus menunjukkan bahwa sebanyak 2 siswa termasuk kategori keaktifan belajar tinggi, 5 siswa termasuk kategori keaktifan belajar sedang, dan sisanya sebanyak 22 siswa termasuk kategori keaktifan belajar rendah. Rata-rata persentase keaktifan belajar siswa hanya 52.5\%. Pada proses pembelajaran pra siklus siswa kurang memperhatikan penjelasan guru, jarang bertanya kepada guru maupun teman tentang materi yang belum jelas, kurang percaya diri dalam menyampaikan pendapat, sering bermain sendiri ketika pembelajaran, dan kurang antusias dalam proses pembelajaran.

Pada siklus I keaktifan belajar siswa mengalami peningkatan. Pada siklus I terdapat 21 siswa dengan kategori keaktifan belajar tinggi, 6 siswa dengan kategori keaktifan belajar sedang, dan 2 siswa dengan kategori keaktifan belajar rendah. Rata-rata persentase keaktifan belajar siswa pada siklus I mencapai 69.5\%. Pada siklus ini aktivitas siswa lebih baik dari pada saat pra tindakan. Sebagian besar siswa sudah memperhatikan penjelasan guru, berani bertanya kepada guru mengenai materi yang belum dipahami, mengerjakan semua tugas yang diberikan oleh guru, dan antusias dalam pembelajaran. Walaupun keaktifan belajar siswa sudah meningkat daripada prasiklus, namun guru masih menemukan kendala. Pada fase diskusi kelompok, pembagian tugas kelompok belum merata sehingga diskusi kelompok didominasi oleh siswa-siswa tertentu. Hal ini dikarenakan siswa belum terbiasa mengerjakan tugas dengan metode diskusi kelompok. Persentase keaktifan belajar siswa juga belum mencapai indikator kinerja yang diharapkan yaitu $75 \%$ sehingga penelitian dilanjutkan pada siklus II.

Pada siklus II keaktifan belajar siswa juga meningkat dibandingkan siklus I. Pada siklus II terdapat 27 siswa dengan kategori keaktifan belajar tinggi dan 2 siswa termasuk kategori keaktifan belajar rendah. Ratarata persentase keaktifan belajar pada siklus II mencapai 82.4\%. Aktivitas siswa pada siklus II lebih baik daripada siklus sebelumya. Siswa memperhatikan penjelasan guru, berani bertanya mengenai materi yang belum dipahami, berani menyampaikan pendapat dalam diskusi kelompok, percaya diri dalam mempresentasikan hasil diskusinya di depan kelas, dan mengerjakan semua tugas yang diberikan oleh guru dengan penuh tanggung jawab. Persentase keaktifan belajar siswa sudah mencapai indikator kinerja yang diharapkan yaitu sebesar 75\% sehingga penelitian dicukupkan hingga siklus II. Rekapitulasi kategori keaktifan belajar siswa disajikan pada tabel berikut ini. 
3178 Peningkatan Keaktifan Belajar Siswa dengan Menerapkan Model Pembelajaran Kooperatif Tipe Student Team Achievement Divisions (STAD) - Nur Rokhanah, Asri Widowati, Eko Hari Sutanto DOI: https://doi.org/10.31004/edukatif.v3i5.860

Tabel 1. Rekapitulasi Kategori Keaktifan Belajar Siswa

\begin{tabular}{|c|c|c|c|}
\hline Kategori & PraSiklus & Siklus I & Siklus II \\
\hline Rendah & 22 & 2 & 0 \\
\hline Sedang & 5 & 6 & 2 \\
\hline Tinggi & 2 & 21 & 22 \\
\hline
\end{tabular}

Adapun peningkatan persentase keaktifan belajar siswa dari prasiklus, siklus I, dan siklus II disajikan dalam diagram berikut ini.

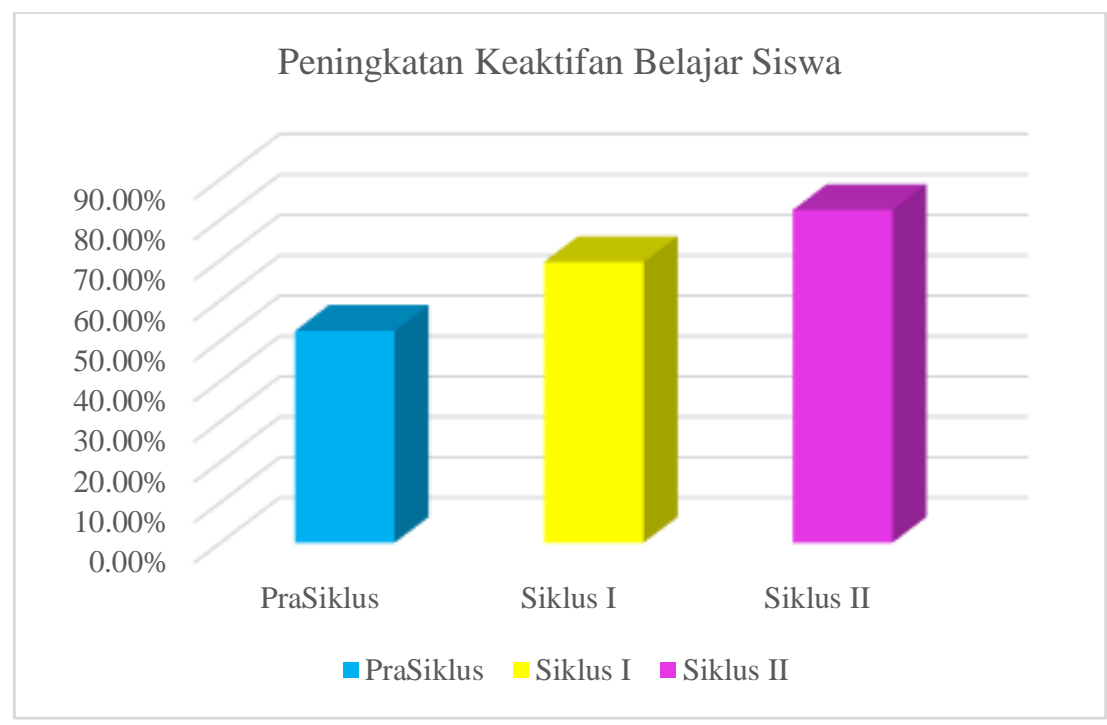

Gambar 1. Diagram Peningkatan Keaktifan Belajar Siswa

Penelitian tindakan kelas ini menunjukkan bahwa keaktifan belajar siswa kelas V SD Negeri 3 Sidoluhur mengalami peningkatan pada setiap siklusnya. Faktor yang mempengaruhi peningkatan keaktifan belajar siswa adalah penerapan model pembelajaran kooperatif tipe Student Team Achievement Divisions (STAD). Pada pembelajaran dengan menerapkan model kooperatif tipe STAD memberikan pengalaman yang bermakna pada siswa kelas V SD Negeri 3 Sidoluhur.

Model pembelajaran kooperatif tipe Student Team Achievement Divisions (STAD) memberikan kesempatan kepada siswa untuk berpartisipasi aktif dalam proses pembelajaran. Adanya pembentukan kelompok dengan tingkat kemampuan anggota yang berbeda-beda memungkinkan siswa untuk saling membantu dalam memahami materi pembelajaran dan bekerjasama untuk meningkatkan keberhasilan kelompok. Hal ini sesuai dengan pendapat Slavin dalam (Isjoni, 2009) yang mengemukakan bahwa keunggulan STAD adalah: a) siswa bekerja sama dalam mencapai tujuan dengan menjunjung tinggi normanorma kelompok; b) siswa aktif membantu dan memotivasi semangat untuk berhasil bersama; c) aktif berperan tutor sebaya untuk lebih meningkatkan keberhasilan kelompok; dan d) interaksi antar siswa seiring dengan peningkatan kemampuan mereka dalam pendapat.

Penerapan model pembelajaran kooperatif tipe Student Team Achievement Divisions (STAD) memberikan dampak positif terhadap meningkatnya keaktifan belajar siswa kelas V SD Negeri 3 Sidoluhur dengan tema Lingkungan Sahabat Kita. Pembelajaran yang sudah diterapkan berpusat pada siswa. Peran guru dalam pembelajaran bukanlah sebagai satu-satunya sumber belajar melainkan sebagai fasilitator yang memfasilitasi siswa untuk aktif menemukan pengetahuan dari berbagai sumber belajar. Adanya fase 
3179 Peningkatan Keaktifan Belajar Siswa dengan Menerapkan Model Pembelajaran Kooperatif Tipe Student Team Achievement Divisions (STAD) - Nur Rokhanah, Asri Widowati, Eko Hari Sutanto DOI: https://doi.org/10.31004/edukatif.v3i5.860

pemberian penghargaan di akhir pembelajaran untuk kelompok yang paling aktif juga memotivasi siswa untuk selalu aktif dari awal hingga akhir pembelajaran.

Pada pelaksanaan pembelajaran dengan menerapkan model kooperatif tipe STAD siswa aktif memperhatikan penjelasan guru dengan seksama, mengerjakan semua tugas yang diberikan, melaksanakan diskusi dengan kelompoknya, mencari informasi dari berbagai sumber belajar, dan bertanya kepada guru maupun teman jika mengalami kesulitan. Hal ini sesuai dengan indikator keaktifan belajar yaitu terlibat dalam keikutsertaan memecahkan masalah, bertanya kepada siswa lain atau guru apabila tidak memahami persoalan yang dihadapi, berusaha mencari berbagai informasi yang diperlukan untuk memecahkan masalah, serta menilai kemampuan diri sendiri dan hasil-hasil yang diperoleh (Sudjana, 2006).

\section{KESIMPULAN}

Berdasarkan hasil pelaksanaan tindakan dan pembahasan yang telah diuraikan, maka dapat disimpulkan bahwa penerapan model pembelajaran kooperatif tipe Student Team Achievement Divisions (STAD) dapat meningkatkan keaktifan belajar siswa kelas V SD Negeri 3 Sidoluhur tahun ajaran 2020/2021. Hal ini dibuktikan dengan persentase skor keaktifan belajar siswa pada siklus I mencapai $69.5 \%$ dan pada siklus II mencapai $82.4 \%$. Berkaitan dengan hasil penelitian yang telah dicapai, penelitian ini diharapkan dapat dijadikan sebagai referensi dalam memberikan informasi tentang pelaksanaan model pembelajaran kooperatif tipe STAD dalam meningkatkan keaktifan belajar siswa.

\section{UCAPAN TERIMA KASIH}

Penulis menyampaikan terimakasih kepada Ibu Dr. Asri Widowati, M.Pd selaku Dosen Pembimbing, Bapak Eko Hari Sutanto, S.Pd selaku Guru Pamong, Bapak/Ibu guru SD Negeri 3 Sidoluhur, rekan-rekan PPG Prajabatan Universitas Negeri Yogyakarta, dan siswa-siswi kelas V SD Negeri 3 Sidoluhur. Semoga penelitian yang disusun dapat bermanfaat bagi semua pihak.

\section{DAFTAR PUSTAKA}

Dimyati \& Mudjiono. (2006). Belajar Dan Pembelajaran. Pt. Rineka Cipta.

Hamalik, O. (2009). Proses Belajar Mengajar. Bumi Aksara.

Handayani, S. (2019). Buku Model Pembelajaran Speaking Tipe Stad Yang Interaktif Fun Game Berbasis Karakter. Uwais Inspirasi Indonesia.

Harahap, N. (2013). Penerapan Model Pembelajaran Kooperatif Tipe Stad Terhadap Hasil Belajar Kognitif, Motivasi, Dan Aktivitas Belajar Siswa Pada Konsep Ekosistem Di Mtsn Model Banda Aceh. Journal Of Petrology, 369(1), 1689-1699.

Isjoni. (2009). Cooperative Learning (Efektivitas Pembelajaran Kelompok). Alfabeta.

Lubis, A. (2012). Pengaruh Model Pembelajaran Kooperatif Tipe Stad Terhadap Hasil Belajar Fisika Siswa Pada Materi Pokok Gerak Lurus Di Kelas X Sma Swasta Uisu Medan. Jurnal Pendidikan Fisika, 1(1), 27-32. Https://Doi.Org/10.22611/Jpf.V1i1.3378

Putri, I. D. C. K., \& Widodo, S. A. (2017). Hubungan Antara Minat Belajar Matematika, Keaktifan Belajar Siswa, Dan Persepsi Siswa Terhadap Prestasi Belajar Matematika Siswa. Prosiding Seminar Nasional Etnomatnesia, 6(3), 721-724. Http;//Ahdadgadgha

Sanjaya, W. (2013). Penelitian Pendidikan, Jenis, Metode Dan Prosedur. Kencana Prenada Media Group.

Saragih, S. \& R. (2013). Peningkatan Kemampuan Komunikasi Matematis Siswa Sma/Ma Di Kecamatan 
3180 Peningkatan Keaktifan Belajar Siswa dengan Menerapkan Model Pembelajaran Kooperatif Tipe Student Team Achievement Divisions (STAD) - Nur Rokhanah, Asri Widowati, Eko Hari Sutanto DOI: https://doi.org/10.31004/edukatif.v3i5.860

Simpang Ulim Melalui Model Pembelajaran Kooperatif Tipe Stad. Jurnal Pendidikan Dan Kebudayaan, 19.

Sardiman, A. M. (2011). Interaksi Dan Motivasi Belajar Mengajar. Rajawali Press.

Sinar. (2018). Metode Active Learning - Upaya Peningkatan Keaktifan Dan Hasil Belajar Siswa. Deepublish Publisher.

Slameto. (2003). Belajar Dan Faktor-Faktor Yang Mempengaruhinya. Rineka Cipta.

Slavin, R. E. (2011). Cooperative Learning: Teori, Risetdan Praktik. Nusa Media.

Sudjana, N. (2006). Penilaian Hasil Proses Belajar Mengajar. Remaja Rosdakarya.

Sugiyono. (2012). Metode Penelitian Kuantitatif, Kualitatif, Dan R\&B. Alfabeta.

Sunilawati, N. M., Dantes, N., \& Candiasa, I. M. (2013). Pengaruh Model Pembelajaran Kooperatif Tipe Stad Kemampuan Numerik Siswa Kelas Iv Sd. E-Journal Program Pascasarjana Universitas Pendidikan Ganesha, 3.

Suparsawan, I. K. (2020). Kolaborasi Pendekatan Saintifik Dengan Model Pembelajaran Stad Geliatkan Peserta Didik. Tata Akbar.

Trianto. (2013). Mendesain Model Pembelajaran Inovatif Progresif. Kencana.

Wahyuningsih, E. S. (2020). Model Pembelajaran Mastery Learning Upaya Peningkatan Keaktifan Dan Hasil Belajar Siswa. Deepublish Publisher.

Wijaya, H., \& Arismunandar, A. (2018). Pengembangan Model Pembelajaran Kooperatif Tipe Stad Berbasis Media Sosial. Jurnal Jaffray, 16(2), 175. Https://Doi.Org/10.25278/Jj71.V16i2.302 